\title{
No túnel da arte perdida
}

A realidadéé uma Cadela, dizJean Baudrillard, em La Pensée Radicale. Demasiado explícito paraserverdadeiro, sustentaoteóricofrancês, o real é uma ilusão dos tempos áureos da crítica moderna. ${ }^{1} \mathrm{Hal}$ Foster, com Recodificação: arte, espetáculo, política cultural, ${ }^{2}$ tenta pegar o último vagão da nostalgia modernista. Professor do departamento de História daA rtedaUniversidadedeCornell, Foster podeser descul pado deal guns deseus julgamentos anacrônicos pelo fato dequeseu livro chegou ao Brasil com 11 anos de atraso. N o campo das discussões sobre o outono da modernidade e o nascimento da pósmodernidade, esseespaço detempo equivale a toda uma era histórica.

Muitas das posições de Foster contra a maldição pós-moderna continuam, porém, a ser defendidas com argumentos mais consistentespor outros. Multiplicam-seacada ano, por exemplo, os discípulosbrasileiros de Fredric Jameson, cujo Pós-modernismo: a lógica cultural do capitalismo tardio foi lançado pela Ática com apenas quatro anos de desvantagem em relação ao seu aparecimento nosEstadosUnidos. ${ }^{3}$ Jameson encarna o mais sofisticado dos analistas de esquerda do pós-moderno. Foster não passa de um simulacro. Erudito, dialoga com Adorno, Habermas, Barthes, Foucault, Baudrillard, Jean-François Lyotard, Paul deMan, etc. Mas - Baudrillard que Ihe interessa é o da crítica da economia sígnica, de 1972, ainda sob a influência dos ventos de $1968 .{ }^{4}$ Uma simples passada de ol hos em Le Crime Parfait ${ }^{5}$ e em Tela total , ${ }^{6}$ dois dos mais recentes mísseis teóricos de Baudrillard, é suficiente para mostrar amudançano imaginário desteautor e na própria natureza conceitual dos fenômenos em discussão.

\footnotetext{
Juremir Machado da Silva

Hal Foster perseguea identidade perdida ea artecapaz deprovocar rupturassemser mero pastiche. "Contra o pluralismo", título do primeiro ensaio do livro, escancara as 
preocupações do ensaísta: adiversidade, filha do relativismo, tornatudo equival ente. Velho discurso contra a mídia, antiga lamentação contraamercantilização davida, pré-histórica denúncia da espetacularização atroz do artístico. Nas entrelinhas, quando não explicitamente, Foster clamapor umaverdade pela qual possa viver emorrer. O espectro de Kierkegaard atormenta-o.

Foster quer resistir à "falácia expressiva”, em nome de legítimos "signos subversivos", e, principalmente, pretende estabelecer um "conceito do político naartecontemporânea", pois não aceita que a cultura seja tomada como umsimplesartefato dedistração, mesmo erudita, da burguesia. Na era da expressão total, sugere, a comunicação está ausente. 0 artista precisaria retomar o seu papel crítico paraajudar a desconstruir o sistema hegemônico perverso. Órfão das vanguardas, $\mathrm{Hal}$ Foster ainda acredita que a arte possa servir de barreira contra a metástase capitalista. N ada como uma boa fantasia para justificar uma vida.

Fora deum paradigma dominante, artísticoe epistemológico, Foster vê apenas a barbárie do ecletismo. A modernidade era crítica; a pós-modernidade, em seu entender, complacente. Esse tipo de simplificação deve encontrar boa clientela no Brasil dos intelectuais que insistem na relação abusiva entrepós-modernidadeeneoliberalismo. No país doPT duro (apenasumadas vertentes do paradoxal ecletismo petista), simulação dos partidos revolucionários do proletariado, o elogio da polissemia tende a ser encarado comoumnovoestágio dabanalização cultural .

Quando nenhum critério universal fundamenta o campo artístico e regulamenta as práticas sociais, a retórica reapropriada por Alain Finkielkraut, "um par de botas vale tanto quanto Shakespeare", ${ }^{7}$ serve de lema paraosvelhosiluministas. Hal Fosterinscrevese, com méritos e defeitos, na linhagem tradicional dos que combatem o neoconservadorismo pós-moderno. Simpático otimista com medo da anarquia, não percebe que o mal émuito maior, mas está em outros lugares ou no não-lugar .

\section{Notas}

1 BAUDRILLARD, Jean, La Pensée Radicale, Paris, Sens \& Tonka, 1994, p. 21.

2 FOSTER, Hal, Recodificação: arte, espetáculo, política cultural, São Paulo, CasaEditorial Paul lista, 1996, 296 páginas.

3 JAMESON, Fredric, Pós-modernismo: a lógica cultural do capitalismo tardio, São Paulo Ática, 1996.

4 BAUDRILLARD, Jean, Pour une critique de l'économie politique du signe, Paris, Gallimard, 1972.

5 BAUDRILLARD, Jean, Le Crime Parfait, Paris, Galilée, 1995.

6 BAUDRILLARD, Jean, Tela total: mito-ironias da era do virtual e da imagem, Porto Alegre, Sulina, 1997.

7 FINKIELKRAUT, Alain, A Derrota do pensamento, Rio de Janeiro, Paz eTerra, 1988, p. 131. 